\title{
P-glycoprotein efflux pump plays an important role in Trypanosoma cruzi drug resistance
}

\author{
Mônica Caroline Oliveira Campos • \\ Denise Barçante Castro-Pinto • Grazielle Alves Ribeiro • \\ Márcia Moreira Berredo-Pinho • \\ Leonardo Henrique Ferreira Gomes • \\ Myrtes Santos da Silva Bellieny • \\ Carla Marins Goulart • Áurea Echevarria • \\ Leonor Laura Leon
}

Received: 14 December 2012 / Accepted: 12 March 2013 /Published online: 10 April 2013

(C) The Author(s) 2013. This article is published with open access at Springerlink.com

\begin{abstract}
Drug resistance in protozoan parasites has been associated with the P-glycoprotein (Pgp), an energydependent efflux pump that transports substances across the membrane. Interestingly, the genes TcPGP1 and TcPGP2 have been described in Trypanosoma cruzi, although the function of these genes has not been fully elucidated. The main goal of this work was to investigate Pgp efflux pump activity and expression in $T$. cruzi lines submitted to in vitro induced resistance to the compounds 4-N-(2-methoxy styryl)-thiosemicarbazone (2-Meotio) and benznidazole (Bz) and to verify the stability of the resistant phenotypes during the parasite life cycle. We observed that the $\mathrm{EC}_{50}$ values for the treatment of epimastigotes with 2-Meotio or $\mathrm{Bz}$ were increased at least 4.7-fold in resistant lines, and this phenotype was maintained in metacyclic trypomastigotes, cell-derived trypomastigotes,
\end{abstract}

M. C. O. Campos $(\bowtie) \cdot$ D. B. Castro-Pinto $\cdot$ G. A. Ribeiro

L. L. Leon

Laboratório de Bioquímica de Tripanosomatídeos, Instituto

Oswaldo Cruz, IOC, Avenida Brasil 4365, Manguinhos, Fundação

Oswaldo Cruz, Rio de Janeiro, Brazil

e-mail: moncacaroline@yahoo.com.br

M. M. Berredo-Pinho

Laboratório de Microbiologia Celular, Instituto Oswaldo Cruz,

IOC, Fiocruz, Rio de Janeiro, Brazil

\section{H. F. Gomes}

Laboratório de Genômica Funcional e Bioinformática, Instituto

Oswaldo Cruz, IOC, Fiocruz, Rio de Janeiro, Brazil

M. S. da Silva Bellieny • C. M. Goulart • Á. Echevarria Departamento de Química, Universidade Federal Rural do Rio de Janeiro, UFRRJ, Rio de Janeiro, Brazil and intracellular amastigotes. However, in epimastigotes, 2-Meotio resistance is reversible, but Bz resistance is irreversible. When compared with the parental line, the resistant lines exhibited higher Pgp efflux activity, reversion of the resistant phenotypes in the presence of Pgp inhibitors, cross-resistance with Pgp modulators, higher basal Pgp ATPase activity, and overexpression of the genes TcPGP1 and TcPGP2. In conclusion, the resistance induced in $T$. cruzi by the compounds 2-Meotio and $\mathrm{Bz}$ is maintained during the entire parasite life cycle. Furthermore, our data suggest the participation of the Pgp efflux pump in T. cruzi drug resistance.

$\begin{array}{ll}\text { Abbreviations } \\ \text { Pgp } & \text { P-glycoprotein } \\ \text { 2-Meotio } & \text { 4- } N \text {-(2'-methoxy styryl)-thiosemicarbazone } \\ \text { Bz } & \text { Benznidazole } \\ \text { MDR } & \text { Multidrug resistance } \\ \text { ABC } & \text { ATP-binding cassette } \\ \text { LIT } & \text { Liver infusion tryptose } \\ \text { PBS } & \text { Phosphate-buffered saline } \\ \text { M15 } & \text { T. cruzi line resistant to 2-Meotio } \\ \text { B15 } & \text { T. cruzi line resistant to Bz } \\ \text { VP } & \text { Verapamil } \\ \text { CsA } & \text { Cyclosporin A } \\ \text { SOV } & \text { Sodium orthovanadate }\end{array}$

\section{Introduction}

Chagas disease, caused by the protozoan parasite Trypanosoma (Schizotrypanum) cruzi, is endemic in Latin America and affects approximately 10 million people (WHO 2010). 
Additionally, the prevalence of the disease has been increasing in non-endemic areas such as North America (Bern et al. 2011) and Europe (Muñoz et al. 2009; Jackson et al. 2010) due to human migration. The only available drugs for the treatment of Chagas disease are benznidazole and nifurtimox, which have limited efficacy during the chronic phase of the infection, require long treatment periods, and have potentially harmful side effects (Castro et al. 2006; Caldas et al. 2008). In addition, several $T$. cruzi strains have shown to be naturally resistant to these compounds (Filardi and Brener 1987), and the resistance may also be induced by maintaining the parasite under prolonged drug pressure (Nirdé et al. 1995; Dos Santos et al. 2008).

The need for a safer and more efficient compound for the treatment of Chagas disease than current alternatives has led several groups to study the trypanocidal properties of natural and synthetic compounds (Campos et al. 2010; Dos Santos Gomes et al. 2012). Recently, Soares et al. (2011) verified that the synthetic compound 4-N-(2'-methoxy styryl)thiosemicarbazone has a potent and selective cytotoxic effect on different developmental forms of $T$. cruzi, encouraging its use in further studies that are focused on finding new treatments for the disease. However, studies have shown that prolonged treatment with thiosemicarbazones in cancer cell lines may induce resistance and that this phenotype is associated with overexpression of the $m d r-1$ gene, which codes for the P-glycoprotein (Pgp) (Rappa et al. 1997; Liu et al. 2009).

Pgp (also known as ABCB1) is a transmembrane protein that belongs to the superfamily of $\mathrm{ABC}$ transporters and acts as an energy-dependent efflux pump to transport substances across membranes (Higgins 1992). This protein has been associated with the multidrug resistance phenotype (MDR), which is characterized by cross-resistance to multiple unrelated cytotoxic agents in tumor cells (Shustik et al. 1995) and protozoan parasites such as Plasmodium falciparum (Wilson et al. 1993), Leishmania tropica (Gamarro et al. 1994), Leishmania amazonensis (GueirosFilho et al. 1995), and Entamoeba histolytica (Descoteaux et al. 1995). Interestingly, the $m d r$-like genes TcPGPl (Torres et al. 1999) and TcPGP2 (Dallagiovanna et al. 1996) have been described in $T$. cruzi, although their drug efflux activity has not been investigated. In the present work, we examined whether the T. cruzi Y strain would develop resistance to thiosemicarbazone and benznidazole (Bz) in vitro and maintain this phenotype through its life cycle, and studied the association between drug resistance and the activity and expression of P-glycoprotein in this parasite.

\section{Material and methods}

Unless specifically indicated otherwise, all reagents were acquired from Sigma Aldrich, Brazil.
Parasite

T. cruzi epimastigotes, Y strain (Silva and Nussenzweig 1953), were cultivated at $26{ }^{\circ} \mathrm{C}$ in liver infusion tryptose medium (LIT medium) supplemented with $10 \%$ heatinactivated fetal calf serum, $100 \mathrm{U} / \mathrm{mL}$ penicillin, and $100 \mathrm{mg} / \mathrm{mL}$ streptomycin. The epimastigote forms were collected during the log phase of cell culture growth.

\section{Effect of the compounds on $T$. cruzi epimastigotes}

Epimastigote forms (final concentration of $5 \times 10^{6} / \mathrm{mL}$ ) were incubated in LIT medium in the presence of the compounds 4$N$-(2-methoxy styryl)-thiosemicarbazone (2-Meotio) (Soares et al. 2011) or Bz ( $N$-Benzyl-2-nitro-1H-imidazole-1-acetamide, Roche, Brazil) prepared in dimethylsulfoxide (Merck, Germany) at concentrations ranging from 25 to $400 \mu \mathrm{M}$ (the final solvent concentration did not exceed 1 . $6 \%$ ). The bioassays were performed at $26^{\circ} \mathrm{C} / 24 \mathrm{~h}$ in 96 -well plates. The cells were counted using a Neubauer chamber to determine the $\mathrm{EC}_{50}$ values, corresponding to the effective dose that kills $50 \%$ of the parasites. Untreated parasites were used as controls.

\section{Induction of resistance to $\mathrm{Bz}$ or 2-Meotio in T. cruzi epimastigotes}

T. cruzi epimastigotes were seeded at $5 \times 10^{6} / \mathrm{mL}$ in LIT medium containing 2-Meotio or $\mathrm{Bz}$ at their respective $\mathrm{EC}_{50}$ concentrations, 71.7 and $182.1 \mu \mathrm{M}$. After $24 \mathrm{~h}$, the medium was replaced with LIT not containing any drug, allowing the replication of surviving parasites. Seven-dayold culture parasites were then submitted to the same respective drug concentrations, and this operation was repeated for ten weekly passages before increasing the drug level (Nirdé et al. 1995). From the 11th passage onwards, the drug concentration used to induce resistance was gradually increased in $10-\mu \mathrm{M}$ steps until the 15th passage was reached. Resistance induction was analyzed by performing a new screening after each passage and comparing the $\mathrm{EC}_{50}$ values. The persistence of the resistant phenotypes was evaluated by cultivating the parasites in vitro without drug pressure for 6 months.

Effect on metacyclic and cell-derived trypomastigotes

To determine whether the resistance would be maintained throughout the parasite life cycle, parental and resistant epimastigotes were cultivated in LIT medium without reposition for 20 days, and the resulting nutritional stress allowed their transformation to metacyclic trypomastigotes. Aiming to kill the remaining epimastigotes, the parasites were treated with $10 \%$ human serum diluted in RPMI-1640 medium for 
$30 \mathrm{~min}$ at $37{ }^{\circ} \mathrm{C}$. After morphological transformation, the parasites were fixed and stained using the Panótico Rápido kit (Laborclin, Pinhais, Parana, Brazil) and examined using light microscopy. Metacyclic trypomastigotes were utilized for (a) a screening assay using the compounds $\mathrm{Bz}$ and 2Meotio, (b) infection of LLC-MK2 cells $\left(1 \times 10^{6}\right.$ parasites $/ 1 \times 10^{5}$ cells) to obtain cell-derived trypomastigotes, and (c) infection of peritoneal macrophages to obtain intracellular amastigotes. The screening protocol for both metacyclic and cell-derived trypomastigotes was the same as those used for the epimastigote forms except for the incubation conditions $\left(37^{\circ} \mathrm{C}\right.$ in a $5 \% \mathrm{CO}_{2}$ atmosphere at $98 \%$ humidity).

Growth inhibition of intracellular amastigotes

Macrophages were isolated from the peritoneal cavity of Balb/c mice in cold RPMI 1640 medium supplemented with $10 \% \mathrm{FCS}$ and $2 \mathrm{mM}$ L-glutamine, $100 \mathrm{U} / \mathrm{mL}$ penicillin, and $100 \mathrm{mg} / \mathrm{mL}$ streptomycin The cells $\left(2 \times 10^{6}\right.$ per well $)$ were maintained at $37{ }^{\circ} \mathrm{C}$ in a humidified $5 \% \mathrm{CO}_{2}$ atmosphere. All assays were carried out using a protocol that was approved by the animal use ethical committee (Comissão de Ética no Uso de Animais CEUA/Fiocruz (P-369/07L-013/08)). These cells were utilized in the following assays:

\section{Cytotoxicity}

The cells were treated with 2-Meotio or $\mathrm{Bz}$ at various concentrations $(12.5$ to $50 \mu \mathrm{M})$ for $24 \mathrm{~h}$, and their viability was measured using the 3-[4,5-dimethylthiazol-2-yl]-2,5diphenyl-tetrazolium bromide dye reduction assay as described by Mosmann (1983). The absorbance was measured at $490 \mathrm{~nm}$ using a VERSAmax tunable spectrophotometer (Molecular Devices, Sunnyvale, CA, USA).

\section{Effect on intracellular amastigotes}

The macrophages were plated in Lab-Tek tissue chamber slides and infected with $2 \times 10^{7}$ metacyclic trypomastigote forms of parental or resistant lines for $3 \mathrm{~h}$. After this time, the cells were cultured in RPMI medium in the absence or presence of various drug concentrations $(12.5$ to $50 \mu \mathrm{M})$ for $24 \mathrm{~h}$. The cultures were fixed with methanol, stained (with Panótico Rápido as described above), and analyzed using optical microscopy. The intracellular amastigotes were quantified as the mean \pm SD of three experiments carried out in duplicate, and the drug activity was analyzed as the endocytic index (number of parasites/100 cells) (Silva et al. 2007).

Rhodamine 123 efflux assay

The parental and resistant lines were resuspended at a density of $5 \times 10^{6}$ parasites $/ \mathrm{mL}$ in phosphate-buffered saline
(PBS), and the resistant lines were incubated at $26{ }^{\circ} \mathrm{C}$ for $15 \mathrm{~min}$ in the presence or absence of $2 \mu \mathrm{M}$ of the Pgp inhibitors verapamil or cyclosporin A (Búa et al. 2008). The parasites were then pelleted at $2,000 \times \mathrm{g}$ for $10 \mathrm{~min}$, resuspended in $1 \mathrm{ml}$ PBS containing $20 \mu \mathrm{g} / \mathrm{mL}$ of Rhodamine 123 fluorescent probe, and incubated for $5 \mathrm{~min}$ at $26{ }^{\circ} \mathrm{C}$. The parasites were washed twice with ice-cold PBS, and the fluorescence was measured at excitation and emission wavelengths of 485 and $530 \mathrm{~nm}$, respectively, using a FACSCalibur flow cytometer (BD Biosciences, San Jose, CA, USA). Experiments were performed using duplicate samples in four independent experiments, and the data were analyzed using Summit software (Dako Colorado Inc., Fort Collins, CO, USA).

\section{Reversion of resistance and cross-resistance assays}

To investigate whether co-treatment of the parasites with $\mathrm{Bz}$ or 2-Meotio plus Pgp inhibitors would revert the resistant phenotype, epimastigote forms of parental and resistant lines were treated with the compounds 2-Meotio or Bz in the presence of $2 \mu \mathrm{M}$ of verapamil or $2 \mu \mathrm{M}$ of cyclosporin A for $24 \mathrm{~h}$ at $26^{\circ} \mathrm{C}$. The treatment of parental, M15 and B15 lines with only $2 \mu \mathrm{M}$ of verapamil or $2 \mu \mathrm{M}$ of cyclosporin $\mathrm{A}$ was performed as a control. The effect of daunorubicin, paclitaxel, and vinblastine on parental and resistant lines was evaluated to verify whether the parasites that were resistant to $\mathrm{Bz}$ or 2-Meotio were also resistant to Pgp modulators. Both assays were performed using the same protocol described in "Effect of the compounds on T. cruzi epimastigotes" section.

\section{Pgp ATPase activity assay}

The abilities of compounds to stimulate ATP hydrolysis were examined using recombinant human Pgp membranes and measured using the Pgp-Glo ${ }^{\mathrm{TM}}$ Assay kit (Promega, Madison, WI, USA). Briefly, $25 \mu \mathrm{g}$ of Pgp was incubated with a range of $\mathrm{Bz}$ or 2-Meotio concentrations $(25-800 \mu \mathrm{M})$ in the presence of $\operatorname{MgATP}(5 \mathrm{mM})$ for $40 \mathrm{~min}$ at $37{ }^{\circ} \mathrm{C}$. Sodium orthovanadate (SOV, an ATPase activity inhibitor) was assayed in parallel. SOVsensitive ATP hydrolysis was determined by subtracting the value obtained using the SOV co-incubated Pgp membrane to those obtained using the SOV-free Pgp membrane. The reaction was measured using a GloMax ${ }^{\circledR}-$ Multi Microplate Luminometer (Promega, Madison, WI, USA). The $\mathrm{EC}_{50}$ (the concentration that stimulates $50 \%$ of ATPase activity) was calculated.

The T. cruzi membrane fractions used were obtained from epimastigote forms of $T$. cruzi parental and resistant lines. Parasites $\left(1 \times 10^{10}\right)$ were resuspended in hypotonic lysis buffer (10 mM Tris- $\mathrm{HCl} \mathrm{pH}$ 7.4-7.6, $10 \mathrm{mM} \mathrm{NaCl}, 1.5 \mathrm{mM} \mathrm{MgCl}_{2}$, 
and $1 \mathrm{mM}$ dithiothreitol) and mechanically lysed as described by Previato et al. (1998). After differential centrifugation $\left(1,500 \times g, 10 \mathrm{~min}\right.$ and $\left.4{ }^{\circ} \mathrm{C}\right)$, the unbroken cells and nuclei were removed, and the enriched membrane fraction was obtained according to Lux et al. (2000). The protein concentration was measured using the Bradford method (Bio-Rad Protein Assay kit, Hercules, CA, USA), and the samples were stored at $-20{ }^{\circ} \mathrm{C}$ until use. These fractions were incubated with $\operatorname{MgATP}(5 \mathrm{mM})$ for $40 \mathrm{~min}$ at $37^{\circ} \mathrm{C}$ in the presence or absence of $\mathrm{Bz}(182$. $1 \mu \mathrm{M})$ or 2-Meotio $(71.7 \mu \mathrm{M})$. In parallel, the fractions were incubated with $100 \mu \mathrm{M}$ cyclosporin A (a specific Pgp ATPase inhibitor). Cyclosporin A-sensitive ATP hydrolysis was determined by subtracting the value obtained using the cyclosporin A co-incubated membrane fraction with that obtained using the Cyclosporin A-free membrane fraction. The ATPase activity of the parental and resistant lines was also evaluated in the presence of non-Pgp ATPase inhibitors [AEO solution: sodium azide, EGTA and ouabain, together with verapamil (a well-known Pgp ATPase activity stimulator) (Ambudkar 1998)].

\section{RNA extraction and quantitative real-time RT-PCR}

Total RNAs from parental and resistant lines of T. cruzi epimastigotes were extracted using TRIzol reagent (Invitrogen, Carlsbad, CA, USA). The 143- and 136-bp segments corresponding to the TcPGP1 (GenBank ID: U95956) and TcPGP2 (GenBank ID: Z49222) genes, respectively, were amplified using the following primers: TcPGP1-forward 5'-GATGCCGATGACGGGATG-3' and $T c P G P 1$-reverse 5'-TCG GTACAAATGTGGAGATGG-3'; $T c P G P 2$-forward $5^{\prime}$-TGGCGTTGT TTATTG TGC-3' and TcPGP2-reverse 5'-GCCACAAGGCACTTCTC-3'. Reverse transcription was carried out using the SuperScript III First-Strand Synthesis System for RT-PCR (Invitrogen, USA). Quantitative real-time RT-PCR was conducted using an ABIPRISM 7500 Sequence Detection System (Applied Biosystems, Foster City, CA, USA) using the Power SYBR Green PCR Master Mix (Applied Biosystems, USA) in a final volume of $25 \mu \mathrm{L}$ according to the manufacturer's specifications. A reaction mixture was prepared containing $1 \mu \mathrm{L}$ of cDNA from each sample mixed with $12.5 \mu \mathrm{L}$ of $2 \times$ Power SYBR Green PCR Master Mix and $1 \mu \mathrm{L}$ of each primer $(400 \mathrm{nmolar} / \mathrm{rx})$ in a final volume of $25 \mu \mathrm{L}$. The cDNA was amplified at $95{ }^{\circ} \mathrm{C}$ for 10 min followed by 40 cycles of $95^{\circ} \mathrm{C}$ for $15 \mathrm{~s}$ and $60^{\circ} \mathrm{C}$ for $1 \mathrm{~min}$. A reverse transcription negative control (without reverse transcriptase) and a non-template negative control were included for each primer set to confirm the absence of genomic DNA and to test for primer dimers and contamination in the reactions, respectively. To ensure that only a single product was amplified, a melting curve analysis was performed. Relative
mRNA levels were normalized against the level of $\beta$ actin (internal reference) mRNA. All data were expressed as the mean $\pm \mathrm{SD}$ of three independent experiments (each in triplicate).

\section{Statistical analysis}

Statistical analyses were performed using one-way analysis of variance and Bonferroni's test (GraphPad Software, La Jolla, CA, USA). Differences were considered significant when $p<0.05$.

\section{Results}

Drug resistance induction and follow-up during the T. cruzi life cycle

The $\mathrm{EC}_{50}$ value for the treatment of epimastigotes with 2Meotio increased from 71.7 to $350.7 \mu \mathrm{M}$ by the 15 th passage under drug pressure. At the same time, the $\mathrm{EC}_{50}$ value for the treatment with $\mathrm{Bz}$ was 4.7 -fold higher in the resistant line (Table 1). The resistant lines obtained after the 15th passage were termed M15 (resistant to 2-Meotio) and B15 (resistant to $\mathrm{Bz}$ ). The resistance induced in the epimastigotes was maintained after transformation to metacyclic trypomastigotes, cell-derived trypomastigotes, and intracellular amastigotes in both the M15 and B15 lines, as seen from the significant increase in $\mathrm{EC}_{50}$ values (Table 2). Additionally, the treatment with 2-Meotio (from 12.5 to $50 \mu \mathrm{M}$ ) did not reduce the endocytic index in cells infected with the M15 line as it did in those infected with the parental line (Fig. 1A, B). Similar results were obtained for the treatment with $\mathrm{Bz}$

Table 1 Induction of resistance to thiosemicarbazone and benznidazole in $T$. cruzi epimastigotes

\begin{tabular}{lll}
\hline Passages $^{\mathrm{a}}$ & \multicolumn{2}{l}{ ED50/24h $(\mu \mathrm{M})^{\mathrm{b}}$} \\
\cline { 2 - 3 } & 2-Meotio & Bz \\
\hline Parental line & $71.7 \pm 4.4$ & $182.1 \pm 10.7$ \\
3rd & $76.6 \pm 4.2$ & $299.1 \pm 2.6$ \\
5th & $125.3 \pm 14.3$ & $357.7 \pm 36.8$ \\
8th & $203.7 \pm 9.1$ & $474.1 \pm 15.7$ \\
10th & $252.8 \pm 9.8$ & $492.5 \pm 14.2$ \\
12th & $350.9 \pm 18.0$ & $684.8 \pm 61.9$ \\
15th & $350.7 \pm 11.2^{\mathrm{c}}$ & $863.3 \pm 53.0^{\mathrm{d}}$ \\
\hline
\end{tabular}

${ }^{a}$ Number of consecutive passages (in vitro) in the presence of each compound

${ }^{\mathrm{b}} \mathrm{Mean} \pm \mathrm{SD}$ of at least three independent experiments

${ }^{\mathrm{c}}$ T. cruzi line resistant to 2-Meotio (M15)

${ }^{\mathrm{d}}$ T. cruzi line resistant to $\mathrm{Bz}(\mathrm{B} 15)$ 
Table 2 Persistence of drug-resistant phenotype during $T$. cruzi life cycle

${ }^{\mathrm{a}}$ Mean \pm SD of at least three independent experiments

${ }^{\mathrm{b}} \mathrm{EC}_{50}$ values based on the endocytic index

\begin{tabular}{|c|c|c|c|c|}
\hline \multirow{3}{*}{ Developmental stage } & \multicolumn{4}{|c|}{$\mathrm{EC}_{50} / 24 \mathrm{~h}(\mu \mathrm{M})^{\mathrm{a}}$} \\
\hline & \multicolumn{2}{|l|}{ 2-Meotio } & \multicolumn{2}{|l|}{$\mathrm{Bz}$} \\
\hline & Parental & M15 & Parental & B15 \\
\hline Epimastigote & $71.7 \pm 4.4$ & $350.7 \pm 11.2$ & $182.1 \pm 10.7$ & $863.3 \pm 53.0$ \\
\hline Metacyclic trypomastigote & $20.4 \pm 1.2$ & $44.2 \pm 2.2$ & $77.3 \pm 5.1$ & $177.4 \pm 13.0$ \\
\hline Culture-derived trypomastigote & $16.7 \pm 3.7$ & $50.3 \pm 6.5$ & $21.1 \pm 1.7$ & $64.9 \pm 2.7$ \\
\hline Intracellular amastigotes ${ }^{\mathrm{b}}$ & $40.9 \pm 3.6$ & $56.8 \pm 6.8$ & $48.4 \pm 1.3$ & $71.2 \pm 6.1$ \\
\hline
\end{tabular}

for cells infected with the parental or B15 lines, showing that the resistant phenotype was maintained (Fig. $1 C$, D). From the fourth month of cultivation in the absence of drug onwards, a continuous decrease in the $\mathrm{EC}_{50}$ value was observed for the treatment with 2Meotio in the M15 line, until it reached the same value as that observed for the parental line (Figs. 2a), indicating reversibility of the resistance. On the other hand, the resistance to $\mathrm{Bz}$ was maintained even after 6 months

A

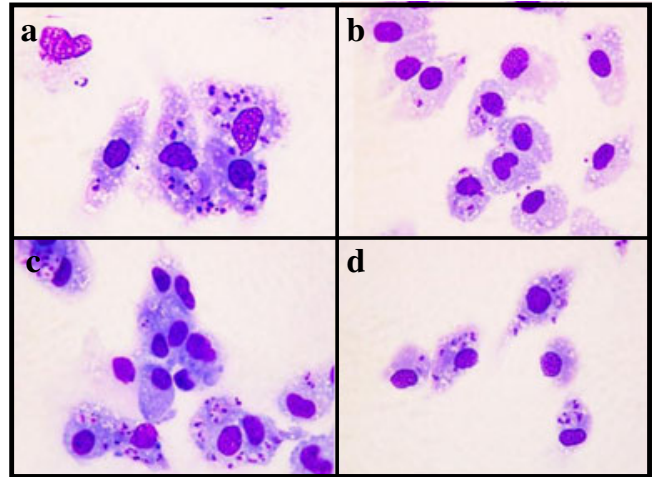

C

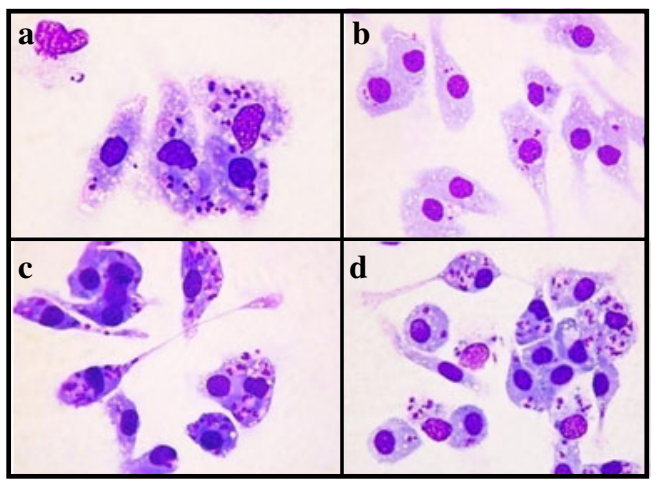

Fig. 1 A The effect of $50 \mu \mathrm{M}$ 2-Meotio on the interaction between peritoneal macrophages and parental or resistant lines of T. cruzi (Y strain) for 24 h. $a, b$ Parental line untreated and treated with 2-Meotio. $c, d$ M15 line untreated and treated with 2-Meotio. Magnification $\times 40$. B Endocytic Index (the percentage of infected cells versus the number of intracellular amastigotes) for the treatment of $T$. cruzi with 2-Meotio. C The effect of of cultivation without drug pressure (Fig. 2b), indicating irreversible resistance.

Pgp efflux activity

To investigate the association between Pgp activity and $T$. cruzi drug resistance, we performed a Rhodamine 123 fluorescence assay. This molecular probe mimics some Pgp substrates and has been used to investigate the Pgp efflux

B

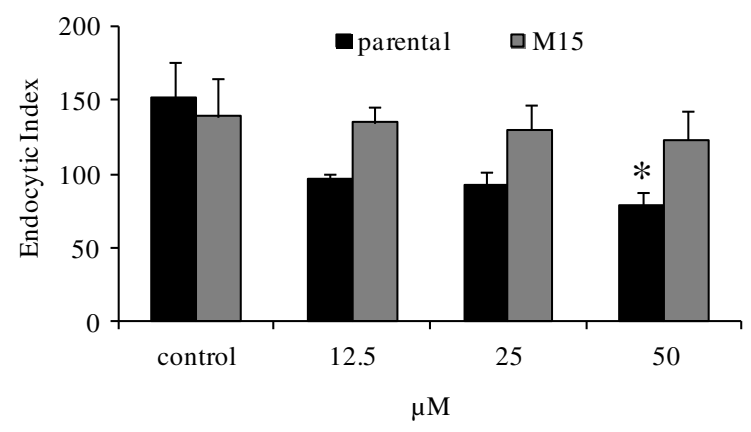

$\mathrm{D}$

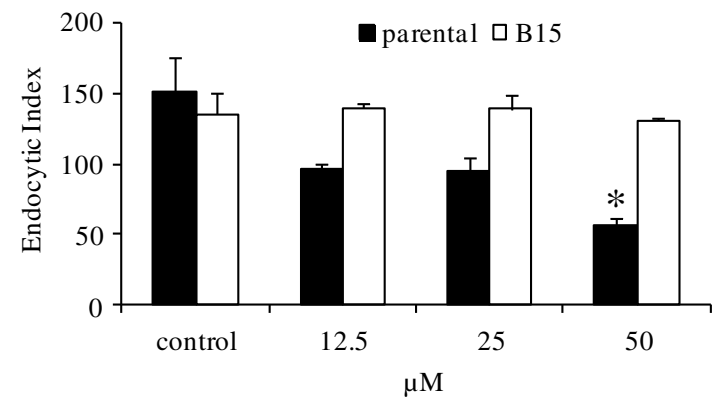

$50 \mu \mathrm{M}$ benznidazole $(\mathrm{Bz})$ on the interaction of peritoneal macrophages with parental or resistant lines of $T$. cruzi (Y strain) for 24 h. $a, b$ Parental line untreated and treated with Bz. $c, d$ B15 line untreated and treated with Bz. Magnification $\times 40$. D Endocytic Index for the treatment of T. cruzi with Bz for $24 \mathrm{~h}$. Asterisk, significant difference in the parental line when comparing the endocytic index in the treated group versus the control 
a
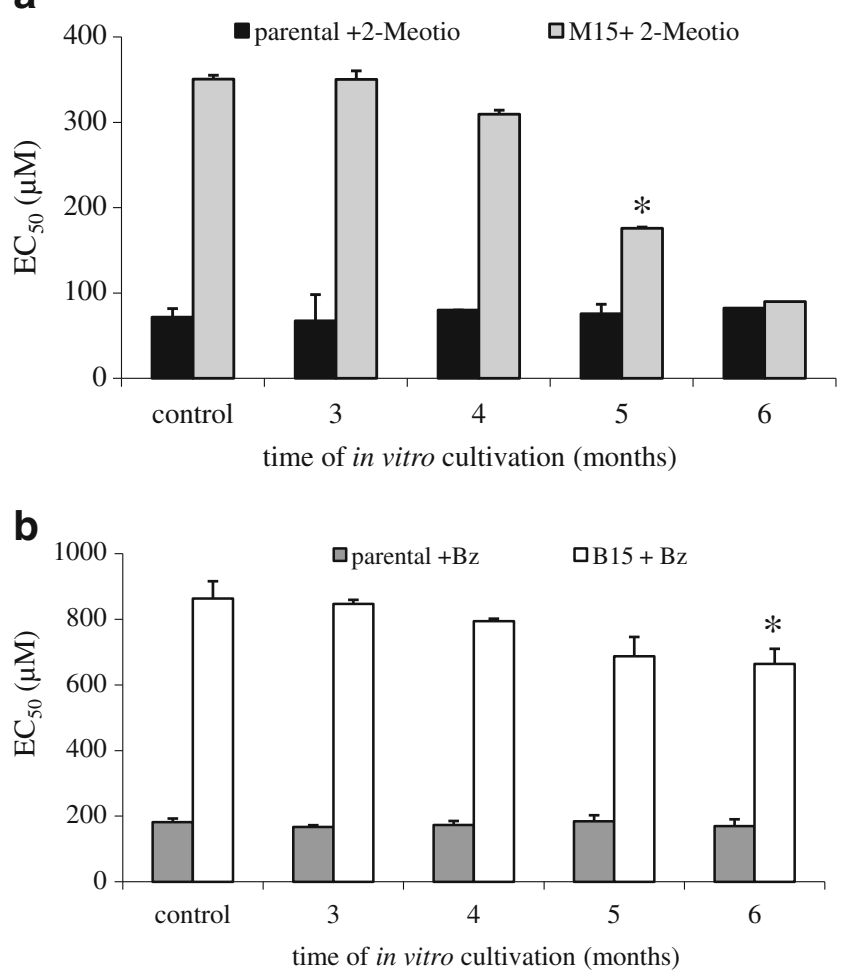

Fig. 2 Maintenance of $T$. cruzi drug resistance after its cultivation without drug pressure. T. cruzi epimastigotes from the parental line and the resistant lines M15 (a) or B15 (b) were cultivated in vitro for 6 months without drug pressure. The concentrations of 2-Meotio or benznidazole that kill $50 \%$ of the parasites $\left(\mathrm{EC}_{50}\right)$ were calculated monthly to determine whether the resistance was maintained. Control refers to the resistant parasites obtained after the 15th passage in the presence of each compound. Asterisk, significant differences between the $\mathrm{EC}_{50}$ values for the M15 and B15 lines compared to the parental line

activity in parasite and human cell lines (Gueiros-Filho et al. 1995; Gupta et al. 2011).

Figure 3 shows that the fluorescence exhibited by the M15 and B15 lines was, respectively, 39.4 and 50.8 \% lower than that exhibited by the parental line, indicating that there was an efflux of Rhodamine by the resistant parasites. Furthermore, Rhodamine fluorescence inside the resistant lines increased significantly after treatment with the Pgp inhibitors cyclosporin A (CsA; Fig. 3a, b) or verapamil (VP; Fig. 3c, d) due to inhibition of the Pgp efflux activity.

To determine whether the resistance phenotype was reversible, the M15 line was co-treated with 2-Meotio plus either CsA or VP (Fig. 3e), and the B15 line was co-treated with Bz plus either CsA or VP (Fig. 3f) in the screening assay. A significant reduction of the $\mathrm{EC}_{50}$ values was observed in comparison with the treatments with 2-Meotio alone (Fig. 3e) or Bz alone (Fig. 3f). In a parallel experiment, it was observed that the treatment with $2 \mu \mathrm{M}$ VP alone or $2 \mu \mathrm{MCA}$ alone did not affect parasite proliferation.

In the cross-resistance assay, it was shown that the M15 line, which is resistant to 2-Meotio, is also more resistant to the compounds Bz, vinblastine, and daunorubicin than is the parental line. It was also observed that the $\mathrm{B} 15$ line is more resistant not only to $\mathrm{Bz}$ but also to the Pgp modulators vinblastine, paclitaxel, and daunorubicin compared to the parental line (Table 3).

Pgp ATPase activity

The effect of various concentrations of 2-Meotio and $\mathrm{Bz}$ on recombinant human Pgp ATPase activity was evaluated. Both compounds stimulated ATPase activity with $\mathrm{EC}_{50}$ values of 134 and $277.1 \mu \mathrm{M}$, respectively [i.e., concentrations that cause a $50 \%$ increase in Pgp ATPase activity (Fig. 4a)]. The effects of cyclosporin A and the AEO solution (which contains three ATPase inhibitors; see "Material and methods" section) were also tested. Verapamil was used as a positive control. Verapamil stimulates, cyclosporin A inhibits, and the AEO solution has no effect on Pgp ATPase activity (see Appendix). Subsequently, the Pgp ATPase activity of T. cruzi-enriched membrane fractions was analyzed. Higher basal Pgp ATPase activity was observed in the membrane fractions of the resistant lines M15 and B15 compared with that observed in the parental line (Fig. 4b, c). In addition, the compounds 2-Meotio or Bz stimulated ATP hydrolyses in the resistant lines M15 and B15, respectively. In parallel, basal Pgp ATPase activity was also evaluated by measuring ATPase activity in the presence of the AEO solution, which inhibits only non-Pgp ATPases, and the previous results were corroborated (see Appendix).

\section{Pgp expression assay}

The expression of the TcPGP1 gene was 1.7 -fold higher in the B15 line and 2.7-fold higher in the M15 line than in the parental line. Similarly, the expression of the TcPGP2 gene was 1.6-fold higher in the B15 line and 1.5-fold higher in the M15 line than in the parental line (Fig. 5).

\section{Discussion}

Drug resistance in $T$. cruzi is considered a major problem for the treatment of Chagas disease, not only because of the natural resistance of some strains to benznidazole (Andrade et al. 1985; Toledo et al. 1997) but also because of the ability of this drug to induce resistance in $T$. cruzi experimentally (Murta and Romanha 1998). This easily achieved resistance phenotype may be associated with the therapeutic failures observed during the chronic phase of the illness because long-term treatment is required to control the infection. In this study, we demonstrated that both benznidazole and the thiosemicarbazone 2-Meotio can induce resistance in the $\mathrm{Y}$ strain of $T$. cruzi in vitro. 
a

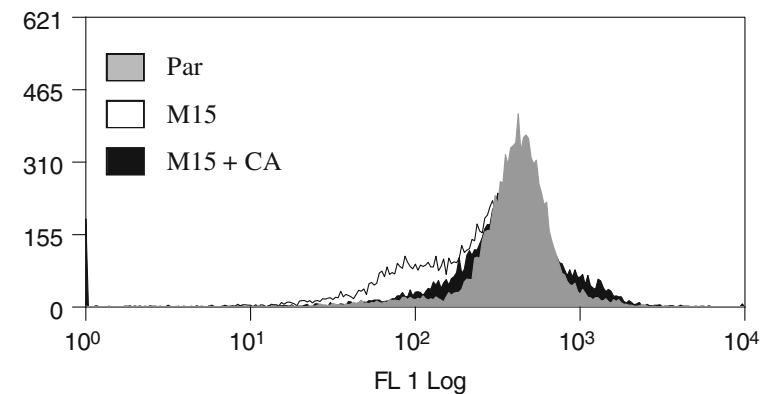

C

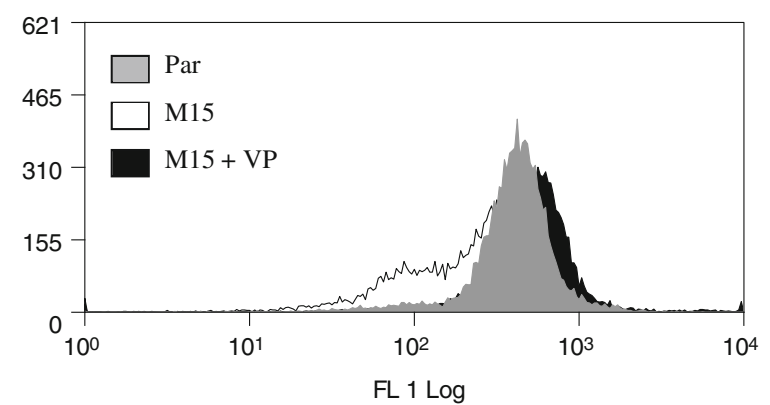

e

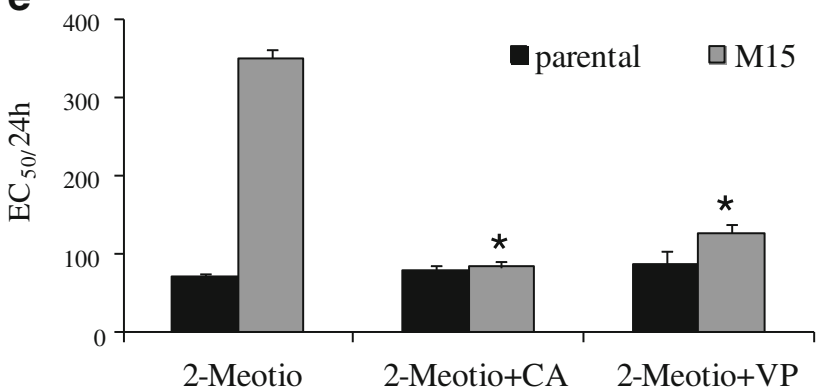

Fig. 3 Histograms showing Rhodamine 123 fluorescence in T. cruzi epimastigotes. Parental line and resistant lines untreated or treated with the Pgp inhibitors cyclosporin A (CsA; a, b) or verapamil (VP; c, d). Reversion of epimastigote resistance by co-treatment with 2-Meotio or $\mathrm{Bz}$ plus Pgp inhibitors. The $\mathrm{EC}_{50}$ values for the treatment of the parental and M15 lines with 2-Meotio plus $2 \mu \mathrm{M}$ of CsA or VP (e)

Resistance to various types of thiosemicarbazones in cancer cell lines has been extensively investigated and appears to be mediated by either qualitative or quantitative alterations in P-glycoprotein. Rappa et al. (1997) b

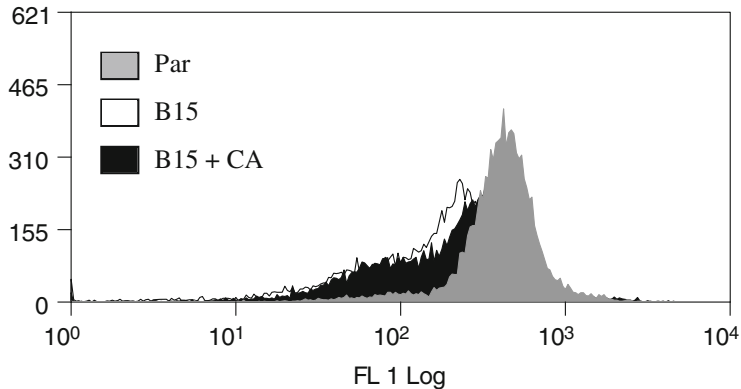

d

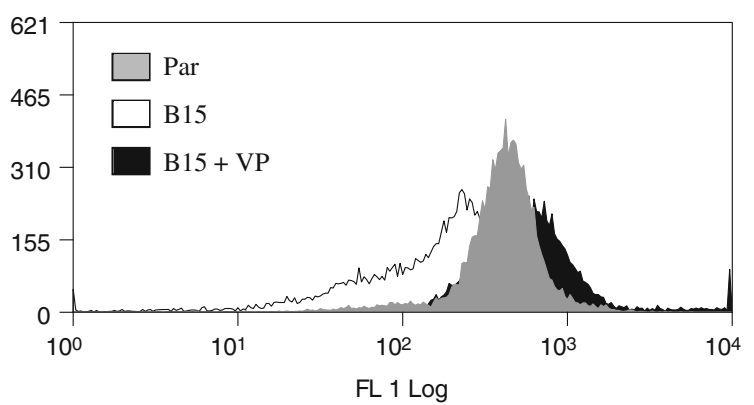

f

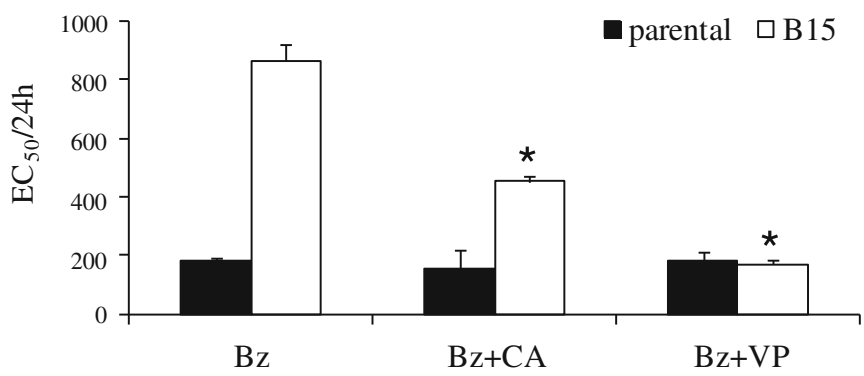

and the treatment of the parental and B15 lines with Bz plus $2 \mu \mathrm{M}$ of CsA or VP were measured (f). Asterisk, significant difference for the lines M15 (e) or B15 (f) comparing the $\mathrm{EC}_{50}$ values obtained after treatment with 2-Meotio or $\mathrm{Bz}$ alone, and in the presence of $\mathrm{Pgp}$ inhibitors

reported that resistance to 3AP in L1210 MQ-580 cells is associated with the overexpression of the multidrug resistance gene $m d r l$. Likewise, Pgp overexpression has also been demonstrated in cancer cell lines that are resistant to the
Table 3 Cross-resistance assay

${ }^{\mathrm{a}} \mathrm{Mean} \pm \mathrm{SD}$ of at least three independent experiments

${ }^{\mathrm{b}}$ Significant difference for each compound in relation to the parental line

\begin{tabular}{|c|c|c|c|c|c|}
\hline & \multicolumn{5}{|c|}{$\mathrm{EC}_{50} / 24 \mathrm{~h}(\mu \mathrm{M})^{\mathrm{a}}$} \\
\hline & 2-Meotio & $\mathrm{Bz}$ & Vinblastine & Paclitaxel & Daunorubicin \\
\hline Parental & $71.7 \pm 4.4$ & $182.1 \pm 10.7$ & $79.5 \pm 8.2$ & $12.9 \pm 2.3$ & $799.7 \pm 73.1$ \\
\hline M15 & $350.7 \pm 11.2^{\mathrm{b}}$ & $345.5 \pm 14.9^{b}$ & $144.2 \pm 10.7^{b}$ & $14.5 \pm 5.3$ & $1,219.7 \pm 97.7^{\mathrm{b}}$ \\
\hline B15 & $80.3 \pm 6.1$ & $863.3 \pm 53.0^{b}$ & $296.7 \pm 18.3^{b}$ & $57.4 \pm 5.2^{b}$ & $1,884.8 \pm 152.8^{b}$ \\
\hline
\end{tabular}


a

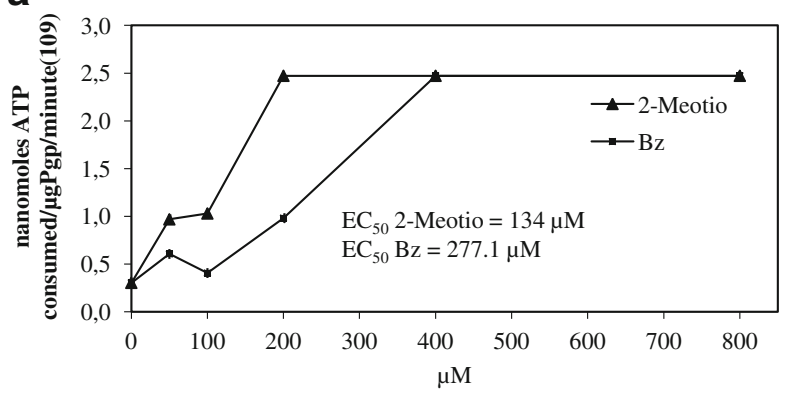

b

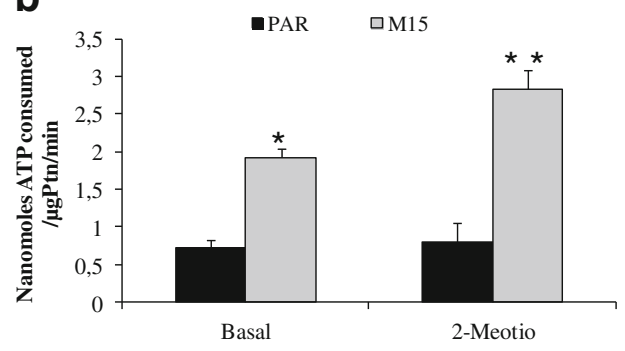

Fig. 4 The effect of various concentrations of 2-Meotio or $\mathrm{Bz}$ on recombinant human Pgp ATPase activity (a). Pgp ATPase activity in the membrane fraction of Parental and M15 lines (b) or parental and B15 lines (c). The basal Pgp ATPase activity was calculated based on the difference between ATPase activity in the untreated sample and in the presence of cyclosporin A $(\mathrm{CsA} ; 100 \mu \mathrm{M})$. The effect of 2-Meotio $(71.7 \mu \mathrm{M})(\mathbf{b})$ or $\mathrm{Bz}(182.1 \mu \mathrm{M})(\mathbf{c})$ on Pgp ATPase activity was calculated based on the difference in ATPase activity in the presence

compounds MAIQ (Cory et al. 1997) and 64Cu-ATSM (Liu et al. 2009). In addition, qualitative modifications, such as

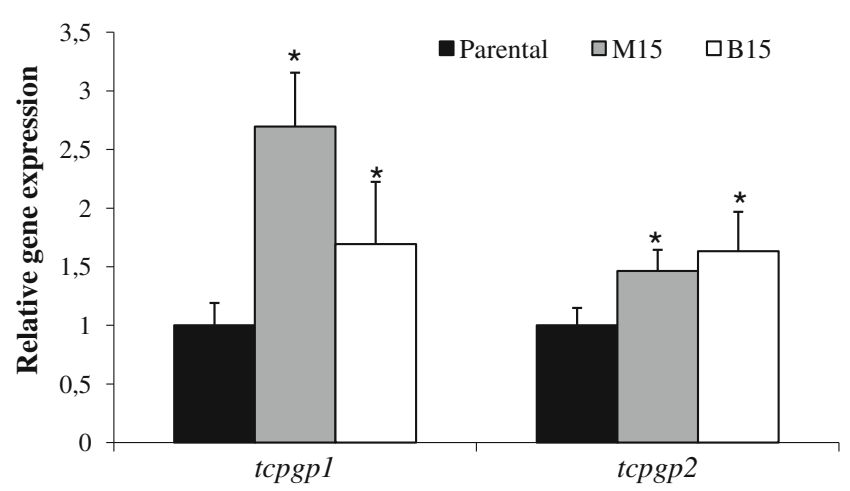

Fig. 5 Relative gene expression of the TcPGP 1 and TcPGP2 tcpgp 2 genes in the parental and resistant lines of T. cruzi quantified using real-time PCR. The values were normalized to the level of the $\beta$-actin gene and expressed as arbitrary units. The values shown are the mean \pm $\mathrm{SD}$ of three experiments performed in triplicate. Asterisk, relative gene expression was compared between M15 and parental lines, or B15 and parental lines. Differences between the values were considered significant when the increase in the gene expression was at least 1.5 -fold higher
C

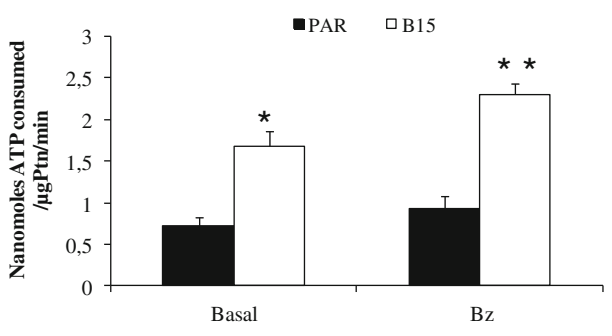

of each compound alone (Bz or 2-Meotio) and the compound plus CsA $(\mathrm{Bz}+\mathrm{CsA}$ or 2-Meotio $+\mathrm{CsA})$. The results are expressed as nanomoles of ATP consumed in the reaction. Asterisk, significant difference for the comparison of basal ATP consumption between the parental line and the lines M15 (b) or B15 (c). Double asterisk, significant difference for the comparison of ATP consumption with and without treatment with 2-Meotio for the M15 line (b) or with Bz for the B15 line (c)

polymorphism of the $m d r 1$ gene, can also result in resistance to thiosemicarbazones (Choi et al. 2010; Traynor et al. 2010).

In T. cruzi epimastigotes ( $\mathrm{Y}$ strain), P-glycoprotein is encoded by two genes, TcPGPl(Torres et al. 1999) and TcPGP2 (Dallagiovanna et al. 1996); both of these genes are presented as a single copy. However, little is known about the physiological role of this protein inside the parasite. It has been suggested that Pgp is involved in the trafficking of heme through the plasma membrane (Lara et al. 2007; Cupello et al. 2011). Our data suggest that this ABCB1 efflux pump is involved in $T$. cruzi drug resistance. It was demonstrated that the resistance to 2-Meotio and benznidazole in epimastigotes is associated with Pgp efflux activity, Pgp ATPase activity, and overexpression of the TcPGP1 and TcPGP2 genes. We also observed that cross-resistance occurs between the studied compounds and some Pgp modulators. These findings are in agreement with the MDR phenotype mediated by Pgp (Ambudkar et al. 1999). Moreover, considering that ATP binding and hydrolysis are recognized as essential conditions for the drug transport activity of Pgp (Horio et al. 1988; Scarborough 1995), the ability of both 2-Meotio and $\mathrm{Bz}$ to stimulate Pgp ATPase activity suggests that these compounds are Pgp 
substrates. Additionally, this is the first study to describe Pgp efflux activity and Pgp ATPase activity in $T$. $c r u z i$, and this finding may contribute to an improved understanding of the biochemical properties of Pgp in this parasite.

Considering that the resistance phenotype was maintained throughout the entire parasite life cycle, an association between Pgp and drug resistance in the other developmental forms of $T$. cruzi can be proposed. Dallagiovanna et al. (1996) have identified the gene $T C P G P 2$ not only in epimastigote forms but also in intracellular amastigotes. However, the TcPGPl gene has been studied only in the epimastigotes of T. cruzi (Torres et al. 1999). For this reason, its identification in the trypomastigote and amastigote forms should be investigated.

Despite the participation of Pgp in the common drug resistance mechanism between lines M15 and B15, these lines differed in the stability of the resistance phenotype in the absence of drug, most likely due to differences in the overall pattern of protein expression. This fact supports the existence of more than one mechanism that act in concert to provide drug resistance in $T$. cruzi. Studies regarding drug resistance to $\mathrm{Bz}$ have reported the participation of proteins associated with parasite metabolism (Portal et al. 2008; Campos et al. 2009) and antioxidant defense (Nogueira et al. 2009; Murta et al. 2008). Alterations in the expression of proteins related to drug metabolism have also been observed (Murta et al. 2006; Mejía-Jaramillo et al. 2011; Mejia et al. 2012). However, an association between Pgp expression and drug resistance has not been found (Murta et al. 2001). Nevertheless, some authors suggest that the in vivo and in vitro resistance to $\mathrm{Bz}$ operate through different mechanisms (Andrade et al. 2008; Villarreal et al. 2005). Until now, the existence of a common drug resistance mechanism has not been described either inside each genetic cluster of T. cruzi or among natural and laboratory-selected resistant lines (Dos Santos et al. 2008).

Interestingly, it was demonstrated that the first generation Pgp inhibitors cyclosporin A and verapamil were able to revert drug resistance to 2-Meotio and Bz in T. cruzi. Similar results have been described by Neal et al. (1989) who observed that co-treatment with nifurtimox and verapamil effectively reversed resistance to nifurtimox in the T. cruzi X10 clone in vitro. Thus, one approach that might be explored for the treatment of Chagas disease is to use a combination of drugs with Pgp reversal agents to prevent the emergence of the Pgp-mediated MDR phenotype. Clinical trials using Pgp reversal agents have been performed to overcome drug resistance in cancer cell lines (Sonneveld et al. 2001; Morjani and Madoulet 2010). Second-, third-, and fourth-generation Pgp inhibitors have been investigated; the last group is considered the most promising because drugs in this group exhibit higher affinity to Pgp and lower toxicity to normal mammal cells (Palmeira et al. 2012).

\section{Conclusions}

Inducing in vitro resistance to benznidazole in the $\mathrm{Y}$ strain of T. cruzi provided an additional model to not only study the characteristics of the resistance phenotype but also evaluate the effect of new compounds on this parasite. Furthermore, our data suggest that the Pgp efflux pump plays a role in $T$. cruzi drug resistance. Knowledge of the mechanism of drug resistance in $T$. cruzi may be helpful for further studies that focus on new drug targets and drug associations aimed at improving the treatment of Chagas disease.

Acknowledgments We would like to thank Coordenação de Aperfeiçoamento de Pessoal de Nível Superior (CAPES), Conselho Nacional de Desenvolvimento Científico e Tecnológico (CNPq), Fundação de Apoio à Pesquisa do Estado do Rio de Janeiro (FAPERJ), and Instituto Oswaldo Cruz (IOC), FIOCRUZ, Brazil for financial support. We also thank Dr. Vera Bongertz for revising the English.

Conflict of interest None to declare.

Open Access This article is distributed under the terms of the Creative Commons Attribution License which permits any use, distribution, and reproduction in any medium, provided the original author(s) and the source are credited.

\section{Appendix}

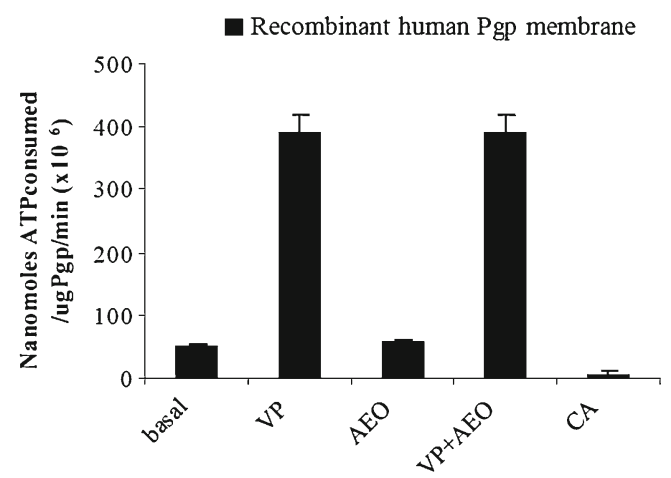

Fig. 6 The effects of verapamil, AEO solution, and cyclosporin A on recombinant human Pgp membrane. Description of data: Standardization of the assay, confirming that verapamil stimulates, cyclosporin A inhibits, and the AEO solution has no effect on Pgp ATPase activity. The effect of these agents on ATP consumption was compared with basal ATP consumption (which was measured based on the difference between ATP consumption in the presence and absence of sodium orthovanadate, a Pgp ATPase activity inhibitor) 
a

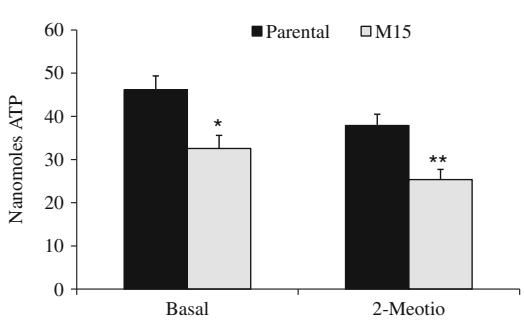

Fig. 7 The effect of 2-Meotio and Bz on Pgp ATPase activity in the membrane fraction of parental and resistant $T$. cruzi lines. Description of data: To confirm the results observed in Fig. 4b, c, thereby overcoming the problem caused by other ATPases contributing to the activity measured in the membrane fractions of $T$. cruzi, we evaluated the consumption of ATP in the membrane fractions in the presence of non-Pgp ATPase inhibitors [AEO solution: sodium azide (inhibits F-type ATPase), ouabain

\section{References}

Ambudkar SV (1998) Drug-stimulatable ATPase activity in crude membranes of human MDR1-transfected mammalian cells. Meth Enzymol 292:504-514

Ambudkar SV, Dey S, Hrycyna CA, Ramachandra M, Pastan I, Gottesman MM (1999) Biochemical, cellular, and pharmacological aspects of the multidrug transporter. Annu Rev Pharmacol Toxicol 39:361-398

Andrade SG, Magalhães JB, Pontes AL (1985) Evaluation of chemotherapy with benznidazole and nifurtimox in mice infected with Trypanosoma cruzi strains of different types. Bull World Health Organ 63:721-726

Andrade HM, Murta SM, Chapeaurouge A, Perales J, Nirdé P, Romanha AJ (2008) Proteomic analysis of Trypanosoma cruzi resistance to benznidazole. J Proteome Res 7:2357-2367

Bern C, Kjos S, Yabsley MJ, Montgomery SP (2011) Trypanosoma cruzi and Chagas disease in the United States. Clin Microbiol Rev $24: 655-681$

Búa J, Fichera LE, Fuchs AG, Potenza M, Dubin M, Wenger RO, Moretti G, Scabone CM, Ruiz AM (2008) Anti-Trypanosoma cruzi effects of cyclosporin A derivatives: possible role of a P-glycoprotein and parasite cyclophilins. Parasitol 135:217228

Caldas IS, Talvani A, Caldas S, Carneiro CM, de Lana M, da Matta Guedes PM, Bahia MT (2008) Benznidazole therapy during acute phase of Chagas disease reduces parasite load but does not prevent chronic cardiac lesions. Parasitol Res 103:413421

Campos FM, Liarte DB, Mortara RA, Romanha AJ, Murta SM (2009) Characterization of a gene encoding alcohol dehydrogenase in benznidazole-susceptible and -resistant populations of Trypanosoma cruzi. Acta Trop 111:56-63

Campos MC, Salomão K, Castro-Pinto DB, Leon LL, Barbosa HS, Maciel MA, de Castro SL (2010) Croton cajucara crude extract and isolated terpenes: activity on Trypanosoma cruzi. Parasitol Res 107:1193-1204

Castro JA, Mecca MM, Bartel LC (2006) Toxic side effects of drugs used to treat Chagas disease (American trypanosomiasis). Hum Exp Toxicol 25:471-479

Choi BS, Alberti DB, Schelman WR, Kolesar JM, Thomas JP, Marnocha R, Eickhoff JC, Ivy SP, Wilding G, Holen KD (2010) The maximum tolerated dose and biologic effects of 3aminopyridine-2-carboxaldehyde thiosemicarbazone (3-AP) in b

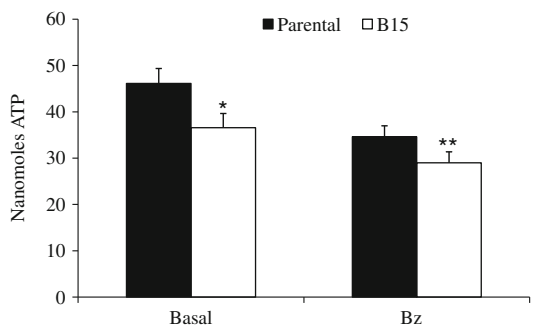

(inhibits $\mathrm{Na}+\mathrm{K}+\mathrm{ATPase}$ ) and EGTA (inhibits $\mathrm{Ca}+2$ ATPase), together with verapamil (a well-known Pgp ATPase activity stimulator)]. The figure shows the concentration of ATP (nanomoles) not consumed. Significant differences for the comparison of basal ATPase activity between parental and resistant lines (asterisk) alone and (double asterisk) in the presence of the compounds 2-Meotio (a) or Bz (b)

combination with irinotecan for patients with refractory solid tumors. Cancer Chemother Pharmacol 66:973-980

Cory JG, Cory AH, Lorico A, Rappa G, Sartorelli AC (1997) Altered efflux properties of mouse leukemia L1210 cells resistant to 4-methyl-5amino-1-formylisoquinoline thiosemicarbazone. Anticancer Res 17(5A):3185-3193

Cupello MP, Souza CF, Buchensky C, Soares JB, Laranja GA, Coelho MG, Cricco JA, Paes MC (2011) The heme uptake process in Trypanosoma cruzi epimastigotes is inhibited by heme analogues and by inhibitors of ABC transporters. Acta Trop 120:211-218

Dallagiovanna B, Gamarro F, Castanys S (1996) Molecular characterization of a P-glycoprotein-related tcpgp 2 gene in Trypanosoma cruzi. Mol Biochem Parasitol 75:145-157

Descoteaux S, Ayala P, Samuelson J, Orozco E (1995) Increase in mRNA of multiple Eh pgp genes encoding P-glycoprotein homologues in emetine-resistant Entamoeba histolytica parasites. Gene 164:179-184

Dos Santos Gomes FO, de Melo CM, Peixoto CA, de Lima Mdo C, Galdino SL, Pereira VR, da Rocha Pitta I (2012) New imidazolidine derivatives as anti-Trypanosoma cruzi agents: structure-activity relationships. Parasitol Res 111:2361-2366

Dos Santos FM, Caldas S, de Assis Cáu SB, Crepalde GP, de Lana M, Machado-Coelho GL, Veloso VM, Bahia MT (2008) Trypanosoma cruzi: induction of benznidazole resistance in vivo and its modulation by in vitro culturing and mice infection. Exp Parasitol 120:385390

Filardi LS, Brener Z (1987) Susceptibility and natural resistance of Trypanosoma cruzi strains to drugs used clinically in Chagas disease. Trans R Soc Trop Med Hyg 81:755-759

Gamarro F, Chiquero MJ, Amador V, Légaré D, Ouellette M, Castanys S (1994) P-glycoprotein overexpression in methotrexate-resistant Leishmania tropica. Biochem Pharmacol 47:1939-1947

Gueiros-Filho FJ, Viola JP, Gomes FC, Farina M, Lins U, Bertho AL, Wirth DF, Lopes UG (1995) Leishmania amazonensis: multidrug resistance in vinblastine-resistant promastigotes is associated with rhodamine 123 efflux, DNA amplification, and RNA overexpression of a Leishmania mdr1 gene. Exp Parasitol 81:480-490

Gupta SV, Sass EJ, Davis ME, Edwards RB, Lozanski G, Heerema NA, Lehman A, Zhang X, Jarjoura D, Byrd JC, Pan L, Chan KK, Kinghorn AD, Phelps MA, Grever MR, Lucas DM (2011) AAPS J 13(3):357-364

Higgins CF (1992) ABC transporters: from microorganisms to man. Annu Rev Cell Biol 8:67-113

Horio M, Gottesman MM, Pastan I (1988) ATP-dependent transport of vinblastine in vesicles from human multidrug resistant cells. Proc Natl Acad Sci USA 85:3580-3584 
Jackson Y, Gétaz L, Wolff H, Holst M, Mauris A, Tardin A, Sztajzel J, Besse V, Loutan L, Gaspoz JM, Jannin J, Albajar Vinas P, Luquetti A, Chappuis F (2010) Prevalence, clinical staging and risk for bloodborne transmission of Chagas disease among Latin American migrants in Geneva, Switzerland. PLoS Negl Trop Dis 4:e592

Lara FA, Sant'anna C, Lemos D, Laranja GA, Coelho MG, Reis Salles I, Michel A, Oliveira PL, Cunha-E-Silva N, Salmon D, Paes MC (2007) Heme requirement and intracellular trafficking in Trypanosoma cruzi epimastigotes. Biochem Biophys Res Commun 355:16-22

Liu J, Hajibeigi A, Ren G, Lin M, Siyambalapitiyage W, Liu Z, Simpson E, Parkey RW, Sun X, Oz OK (2009) Retention of the radiotracers 64CuATSM and 64Cu-PTSM in human and murine tumors is influenced by MDR1 protein expression. J Nucl Med 50(8):1332-1339

Lux H, Heise N, Klenner T, Hart D, Opperdoes FR (2000) Ether-lipid (alkylphospholipid) metabolism and the mechanism of action of ether-lipid analogues in Leishmania. Mol Biochem Parasitol 111:1-14

Mejia AM, Hall BS, Taylor MC, Gómez-Palacio A, Wilkinson SR, Triana-Chávez O, Kelly JM (2012) Benznidazole-resistance in Trypanosoma cruzi is a readily acquired trait that can arise independently in a single population. J Infect Dis 206:220-228

Mejía-Jaramillo AM, Fernández GJ, Palacio L, Palacio L, TrianaChávez O (2011) Gene expression study using real-time PCR identifies an NTR gene as a major marker of resistance to benznidazole in Trypanosoma cruzi. Parasit Vectors 4:169

Morjani H, Madoulet C (2010) Immunosuppressors as multidrug resistance reversal agents. Meth Mol Biol 596:433-446, Review

Mosmann T (1983) Rapid colorimetric assay for cellular growth and survival: application to proliferation and cytotoxicity assays. J Immunol Meth 65:55-63

Muñoz J, Gómez i Prat J, Gállego M, Gimeno F, Treviño B, LópezChejade P, Ribera O, Molina L, Sanz S, Pinazo MJ, Riera C, Posada EJ, Sanz G, Portús M, Gascon J (2009) Clinical profile of Trypanosoma cruzi infection in a non-endemic setting: immigration and Chagas disease in Barcelona (Spain). Acta Trop 111:51-55

Murta SM, Romanha AJ (1998) In vivo selection of a population of Trypanosoma cruzi and clones resistant to benznidazole. Parasitology 116(Pt 2):165-171

Murta SM, dos Santos WG, Anacleto C, Nirdé P, Moreira ES, Romanha AJ (2001) Drug resistance in Trypanosoma cruzi is not associated with amplification or overexpression of $\mathrm{P}$ glycoprotein (PGP) genes. Mol Biochem Parasitol 117:223-228

Murta SM, Krieger MA, Montenegro LR, Campos FF, Probst CM, Avila AR, Muto NH, de Oliveira RC, Nunes LR, Nirdé P, BrunaRomero O (2006) Deletion of copies of the gene encoding old yellow enzyme (TcOYE), a NAD(P)H flavin oxidoreductase, associates with in vitro-induced benznidazole resistance in Trypanosoma cruzi. Mol Biochem Parasitol 146:151-162

Murta SM, Nogueira FB, Dos Santos FM, Campos PF, Volpe C, Liarte DB, Nirdé P, Probst CM, Krieger MA, Goldenberg S, Romanha AJ (2008) Differential gene expression in Trypanosoma cruzi populations susceptible and resistant to benznidazole. Acta Trop 107:59-65

Neal RA, van Bueren J, McCoy NG, Iwobi M (1989) Reversal of drug resistance in Trypanosoma cruzi and Leishmania donovani by verapamil. Trans R Soc Trop Med Hyg 83:197-198

Nirdé P, Larroque C, Barnabé C (1995) Drug-resistant epimastigotes of Trypanosoma cruzi and persistence of this phenotype after differentiation into amastigotes. C R Acad Sci III 318:1239-1244

Nogueira FB, Ruiz JC, Robello C, Romanha AJ, Murta SM (2009) Molecular characterization of cytosolic and mitochondrial tryparedoxin peroxidase in Trypanosoma cruzi populations susceptible and resistant to benznidazole. Parasitol Res 104:835-844

Palmeira A, Sousa E, Vasconcelos MH, Pinto MM (2012) Three decades of P-gp inhibitors: skimming through several generations and scaffolds. Curr Med Chem 19:1946-2025
Portal P, Villamil SF, Alonso GD, De Vas MG, Flawiá MM, Torres HN, Paveto C (2008) Multiple NADPH-cytochrome P450 reductases from Trypanosoma cruzi suggested role on drug resistance. Mol Biochem Parasitol 160:42-51

Previato JO, Sola-Penna M, Agrellos OA, Jones C, Oeltmann T, Travassos LR, Mendonça-Previato L (1998) Biosynthesis of $\mathrm{O}-\mathrm{N}$ acetylglucosamine-linked glycans in Trypanosoma cruzi. Characterization of the novel uridine diphospho- $N$-acetylglucosamine: polypeptide $\mathrm{N}$-acetylglucosaminyltransferase-catalyzing formation of $\mathrm{N}$-acetylglucosamine alpha1-O-threonine. J Biol Chem 273(24):14982-14988

Rappa G, Lorico A, Liu MC, Kruh GD, Cory AH, Cory JG, Sartorelli AC (1997) Overexpression of the multidrug resistance genes mdr1, mdr3 and mrp in L1210 leukemia cells resistant to inhibitors of ribonucleotide reductase. Biochem Pharmacol 54:649-655

Scarborough GA (1995) Drug-stimulated ATPase activity of the human P-glycoprotein. J Bioenerg Biomembr 27(1):37-41, Review

Shustik C, Dalton W, Gros P (1995) P-glycoprotein-mediated multidrug resistance in tumor cells: biochemistry, clinical relevance and modulation. Mol Aspects Med 16:1-78

Silva LHP, Nussenzweig V (1953) Sobre uma cepa de Trypanosoma cruzi altamente virulenta para o camundongo branco. Folha Clin Biol 20:191-208

Silva CF, Meuser MB, De Souza EM, Meirelles MN, Stephens CE, Som P, Boykin DW, Soeiro MN (2007) Cellular effects of reversed amidines on Trypanosoma cruzi. Antimicrob Agents Chemother 51:3803-3809

Soares RO, Echevarria A, Bellieny MS, Pinho RT, de Leo RM, Seguins WS, Machado GM, Canto-Cavalheiro MM, Leon LL (2011) Evaluation of thiosemicarbazones and semicarbazones as potential agents anti-Trypanosoma cruzi. Exp Parasitol 129:381-387

Sonneveld P, Suciu S, Weijermans P, Beksac M, Neuwirtova R, Solbu G, Lokhorst H, van der Lelie J, Dohner H, Gerhartz H, Segeren CM, Willemze R, Lowenberg B, European Organization for Research and Treatment of Cancer (EORTC), Leukaemia Cooperative Group (LCG), Dutch Haemato-Oncology Cooperative Study Group (HOVON) (2001) Cyclosporin A combined with vincristine, doxorubicin and dexamethasone (VAD) compared with VAD alone in patients with advanced refractory multiple myeloma: an EORTC-HOVON randomized phase III study (06914). Br J Haematol 115:895-902

Toledo MJ, Guilherme AL, da Silva JC, de Gasperi MV, Mendes AP, Gomes ML, de Araújo SM (1997) Trypanosoma cruzi: chemotherapy with benznidazole in mice inoculated with strains from Paraná state and from different endemic areas of Brazil. Rev Inst Med Trop Sao Paulo 39:283-290

Torres C, Barreiro L, Dallagiovanna B, Gamarro F, Castanys S (1999) Characterization of a new ATP-binding cassette transporter in Trypanosoma cruzi associated to L1Tc retrotransposon. Biochem Biophys Acta 1489:428-432

Traynor AM, Lee JW, Bayer GK, Tate JM, Thomas SP, Mazurczak M, Graham DL, Kolesar JM, Schiller JH (2010) A phase II trial of triapine (NSC\# 663249) and gemcitabine as second line treatment of advanced non-small cell lung cancer: Eastern Cooperative Oncology Group Study 1503. Invest New Drugs 28:91-97

Villarreal D, Nirdé P, Hide M, Barnabé C, Tibayrenc M (2005) Differential gene expression in benznidazole-resistant Trypanosoma cruzi parasites. Antimicrob Agents Chemother 49(7):2701-2709

Wilson CM, Volkman SK, Thaithong S, Martin RK, Kyle DE, Milhous WK, Wirth DF (1993) Amplification of $p f m d r 1$ associated with mefloquine and halofantrine resistance in Plasmodium falciparum from Thailand. Mol Biochem Parasitol 57:151-160

World Health Organization (WHO) 2010 Chagas disease (American trypanosomiasis) [http://www.who.int/mediacentre/factsheets/ fs $340 /$ en/index.html] 